\title{
elyra
}

\section{O nomadismo poético nos poemas-colagens de Rui Pires Cabral}

\author{
Tamy de Macedo Pimenta \\ Universidade Federal Fluminense
}

Resumo: Este artigo propõe-se a analisar as relações intermidiáticas presentes em três livros do poeta português contemporâneo Rui Pires Cabral - a saber, Biblioteca dos rapazes (2012), Broken (2013) e Oh! Lusitania (2014) -, que fazem uso de poemas-colagens. Para tal, utilizamos como base teórica escritos sobre intermidialidade, citação e colagem a fim de compreender o movimento estabelecido por essa poesia a partir de um processo criativo dinâmico ao qual chamamos "nomadismo poético".

Palavras-chave: Rui Pires Cabral, nomadismo poético colagem

\begin{abstract}
This article aims at analyzing the intermedial relations in three books written by the Portuguese contemporary poet Rui Pires Cabral, named Biblioteca dos rapazes (2012), Broken (2013) and Oh! Lusitania (2014), which use collage-poems. For that purpose, a theoretical basis is adopted bearing on intermediality, quotation and collage, in order to understand the movement created by this poetry through a dynamic creative process that we call "poetic nomadism".
\end{abstract}

Keywords: Rui Pires Cabral, poetic nomadismo, collage 
Como se o escritor sentisse a necessidade de recorrer à ficção de uma dependência da imagem para afirmar sua autonomia, a radical heterogeneidade do texto, para reinventar sua prática escritural, para colocar à prova os poderes - ou, mais raramente, os limites - da escritura.

Mourier-Sasile/ Moncond'huy 1994 apud Arbex $2006^{1}$

O poeta brasileiro Manoel de Barros disse certa vez em entrevista que "O andarilho é um ser errático - igual a poesia" (Barros 2006). A poética de Rui Pires Cabral, poeta que nos interessa neste texto, parece ecoar essa ideia, uma vez que seus versos são repletos de menções a movimentos errantes pelo espaço (sobretudo em seus primeiros livros, com ênfase significativa em viagens) e compreendem e concebem a poesia como "uma aventura errática" (Barros 2009), construindo "uma forma poética propositalmente instável, em fuga" (Süssekind 2005: 79). Desse modo, o poeta aproxima-se dos escritores aludidos por Mourier-Sasile e Moncond'huy ao problematizar seu próprio fazer, trazendo esses questionamentos ao corpo poemático.

Em suas primeiras publicações, o trabalho com a citação se dá por dois modos principais: através do diálogo entre poesia e música, com trechos de canções sendo inseridos em meio aos versos ou funcionando como títulos de poemas (cujo maior exemplo encontra-se na primeira seção de Música antológica \& Onze cidades, de 1997, em que todos os poemas têm seus títulos retirados de músicas); e por meio da apropriação de fragmentos literários alheios aos poemas, igualmente sendo usados junto aos versos ou nos títulos (como pode-se observar em Oráculos de cabeceira, de 2009, cujos títulos dos poemas são trechos retirados de obras literárias diversas, indicadas por notas ao final do livro).

Assim, já em suas primeiras obras, o poeta se insere em um fenômeno cada vez mais recorrente na literatura dos fins do século XX e início do XXI, no qual ocorre uma fusão ainda maior entre as mais variadas manifestações artísticas. Como enfatiza a crítica americana Marjorie Perloff (2013), publicações compostas por várias citações e alusões mobilizaram a poética e crítica do século $X X$, tornando possível a expansão de técnicas semelhantes na poesia mais recente, na contemporaneidade, de modo que: 
No clima do novo século [...] parecemos estar testemunhando uma reviravolta poética do modelo de resistência da década de 1980 para o diálogo - um diálogo com textos anteriores ou outras mídias, com a técnica do "escrever-através" ou écfrases que permitam ao poeta participar de um discurso maior e mais público. A inventio está cedendo espaço para a apropriação, a restrição elaborada, a composição visual e sonora e a dependência da intertextualidade. (Perloff 2013: 40-41)

Embora Perloff se tenha baseado principalmente no cenário americano, enten demos ser possível utilizar as descrições citadas para pensar a poesia ocidental contemporânea, já que as observações levantadas pela autora se relacionam com um fenômeno global da literatura. Sendo assim, pode-se perceber tal diálogo com outros textos e outras mídias na produção portuguesa mais recente, especialmente nos poetas cujas obras datam dos anos 90 em diante, onde se insere a obra poética aqui estudada. Integrada nesse processo, portanto, a poesia de Rui Pires Cabral faz uso extenso da citação e do diálogo com outras mídias, conforme observado anteriormente, e isso tornou-se ainda mais visível em seus livros mais recentes, com os poemas-colagens criados pelo autor, dos quais trataremos mais adiante.

Conforme apontado por diversos estudos acerca dessa poética, um de seus temas recorrentes é o da viagem, da errância por diversos lugares. Trata-se de "uma lírica que navega, no nosso tempo, o mapa de uma epopeia às índias-de-si-mesmo" (Dal Farra 2007: 11), constituída por um sujeito lírico que percorre incessantemente territórios sem, todavia, ser capaz de pertencer a nenhum deles. Um estrangeiro permanente que insiste em andar, tal qual um nômade:

\author{
[...] Tu nunca quiseste \\ pertencer. Só à ponta da navalha. Só no fundo \\ do beco, encurralado. Meu Deus, que vocação \\ para o desassossego. Mas será um sinal de resistência \\ ou uma espécie de defeito anímico? Tanto faz, \\ vamos, põe a cafeteira ao lume. E recomeça. (Cabral 2005: 29)
}

É possível, desse modo, relacionar essa movimentação com o nomadismo, trazendo inclusive a resistência que lhe é intrínseca, conforme salientaram os pensadores Gilles Deleuze e Félix Guattari, e também o sociólogo Michel Maffesoli. ${ }^{2}$ Nesse sentido, se o 
nomadismo se faz presente nessa poesia pelas características acima elencadas, podemos, ao mesmo tempo, ampliar este conceito a fim de também abarcar a ideia de uma movimentação formal estabelecida pelo uso da citação e da colagem. O nomadismo geográfico, calcado na errância territorial, pode ser então relacionado a um nomadismo poético, entendido como um processo de composição lírica que, ao percorrer diferentes mídias através da poesia, afrouxa as barreiras que separam objetos midiáticos distintos e leva-nos em direção a um entendimento mais amplo de poesia, constantemente problematizando os limites do poético. Se o nomadismo geográfico é vinculado à resistência pela revolta intrínseca contra o sedentarismo, o poético profere a todo instante uma inquietante força que impede amarras e delimitações e, assim, ambos movimentos indicam uma postura resistente, que se nega a determinar e fixar moradas, seja no âmbito territorial ou textual.

Ao falarmos de mídia, entendemos intermidialidade como "um termo genérico para todos aqueles fenômenos que (como indica o prefixo inter-) de alguma maneira acontecem entre as mídias" (Rajewsky 2012: 18) e, desse modo, podemos pensar, de acordo com Rajewsky, em três subcategorias de relações entre mídias: as que envolvem transposição midiática, com a transformação de um determinado produto de mídia em outra mídia (da qual a adaptação cinematográfica de obras literárias é o maior exemplo); as feitas por meio da combinação de mídias, quando há articulação entre duas ou mais mídias na construção do produto (em performances, teatro, instalações e etc.); e as relativas a referências intermidiáticas, quando ocorrem evocações ou citações de uma mídia em outra (encontradas quando um personagem de um filme recita um poema, por exemplo). ${ }^{3}$

Rui Pires Cabral realiza em sua poesia quase todos os tipos de relações intermidiáticas supracitadas. Logo, é possível entender o nomadismo poético presente em sua obra como uma manifestação da intermidialidade na qual o poema incorpora outras mídias, constituindo-se em uma forma poética fluida, informe e permanentemente errante. Muito embora esse processo ocorra em vários momentos da obra poética em questão - por meio da aproximação entre poesia e música e pela apropriação de trechos de obras literárias aos versos, como já mencionado - buscaremos neste texto demonstrar como isso ocorre em três livros publicados entre os anos de 2012 e 2014, nos quais chama a atenção a relação 
acentuada entre poesia e colagem, conforme observaremos. Nesses livros, assim como em outros, Rui Pires Cabral faz uso extenso da citação, técnica relacionada por Antoine Compagnon (2013: 11-12) com a ação infantil do recortar e colar, prática primeira do papel:

\begin{abstract}
Recorte e colagem são o modelo do jogo infantil [...] Construo um mundo à minha imagem, um mundo onde me pertenço, e é um mundo de papel [...] Recorte e colagem são as experiências fundamentais com o papel, das quais a leitura e a escrita não são senão formas derivadas, transitórias, efêmeras [...] É por isso que se deve conservar a lembrança dessa prática original do papel, anterior à linguagem, mas que o acesso à linguagem não suprime de todo, para seguir seu traço sempre presente, na leitura, na escrita, no texto, cuja definição menos restritiva (a que eu adoto) seria: o texto é a prática do papel [...] E no texto, como prática complexa do papel, a citação realiza, de maneira privilegiada, uma sobrevivência que satisfaz à minha paixão pelo gesto arcaico do recortar-colar.
\end{abstract}

Isto posto, podemos atribuir ao uso da citação, inclusive pelo poeta aqui estudado, a mescla da experiência infantil do papel (recorte e colagem) com sua prática complexa (texto). Ao apropriar-se de canções e frases de outros autores, RPC 4 recorta os trechos que escolhe e cola-os, inserindo-os em um novo e outro texto, de forma a realizar a antiga distração da criança de recortar e colar papéis:

Entre a infância e a senilidade, que terei feito? Terei aprendido a ler e a escrever. Leio e escrevo. Não paro de ler e escrever. E por quê? Não seria pela única razão inconfessável de que, no momento, não posso me dedicar inteiramente ao jogo de papel que satisfaria o meu desejo? A leitura e a escrita são substitutos desse jogo. (idem: 11)

Associadas ao recorte e à colagem, a leitura e a escrita ganham um teor ainda mais manual, relacionado às artes plásticas, na medida em que envolvem processos de remoção, deslocamentos e combinações variados. O leitor passa então a escritor, ao selecionar os trechos a serem reintroduzidos a outro contexto: "Gosto do segundo tempo da escrita, quando recorto, junto e recomponho. Antes ler, depois escrever: momentos de puro prazer preservado. Será que eu não preferiria recortar as páginas e colá-las num outro lugar, em desordem, misturando de qualquer jeito?" (idem: 11-12). Em 2012, Rui Pires Cabral realizou o desejo anunciado por Compagnon, muito embora estivesse longe de misturar seus recortes "de qualquer jeito": Biblioteca dos rapazes marca uma nova etapa dessa poesia, 
introduzindo uma forma diferenciada do fazer poético através da justaposição de imagens e frases removidas de fontes diversas. Na nota do autor ao início do livro, lemos:

\begin{abstract}
Os poemas que compõem este livro foram inspirados por velhos romances de aventuras e exemplares diversos de literatura juvenil, maioritariamente editados entre as décadas de 30 e 70 do século passado. E quando digo inspirados, digo-o no sentido mais material possível, já que muitos dos versos publicados nestas páginas foram originariamente compostos com palavras e expressões recortadas desses mesmos livros (veja-se, nas páginas finais, a lista das fontes bibliográficas). Por motivos de ordem gráfica, poética e prática, esses textos primitivos foram depois passados a computador e desenvolvidos. Mas, em todos os casos, a sua introdução na página fez-se pelo método artesanal: manualmente, com tesoura e cola.

Quanto às imagens que complementam os textos - e a ideia fundamental deste livro foi, desde o início, a de casar a poesia com a colagem -, são de natureza e proveniência muito variadas: revistas e postais antigos, fotografias de anónimos, velhas enciclopédias juvenis, calendários, monografias fotográficas de cidades estrangeiras, além das estampas e ilustrações dos livros acima referidos. Em muitos casos, não foi sem algum remorso que me dispus a cortar e a rasgar esses comovedores testemunhos de outras épocas - resta-me a esperança de que o leitor não julgue totalmente inglória a sua destruição. (Cabral 2012: 5)
\end{abstract}

Se as fontes das imagens são diversificadas, as textuais resumem-se a livros infantojuvenis de aventura (sendo 16 das 36 publicações utilizadas da autoria de Júlio Verne). Tal fato é indicado também no próprio título do livro, que alude à coleção "Biblioteca dos rapazes" da editora Portugália, formada por romances de aventura como $A$ ilha do tesouro, As aventuras de Tom Sawyer e outros. Assim, dispostas pelas páginas de maneira dispersa, as imagens e expressões se repetem e complementam, com fragmentos espalhados ao longo das três colunas em que se dividem todos os poemas do livro. Essa aparente desorientação de imagens, entretanto, forma em cada poema um todo coeso de sentido, ligando-se ao conteúdo expresso pelas frases - transformadas em versos -, como podemos observar no exemplo abaixo: 

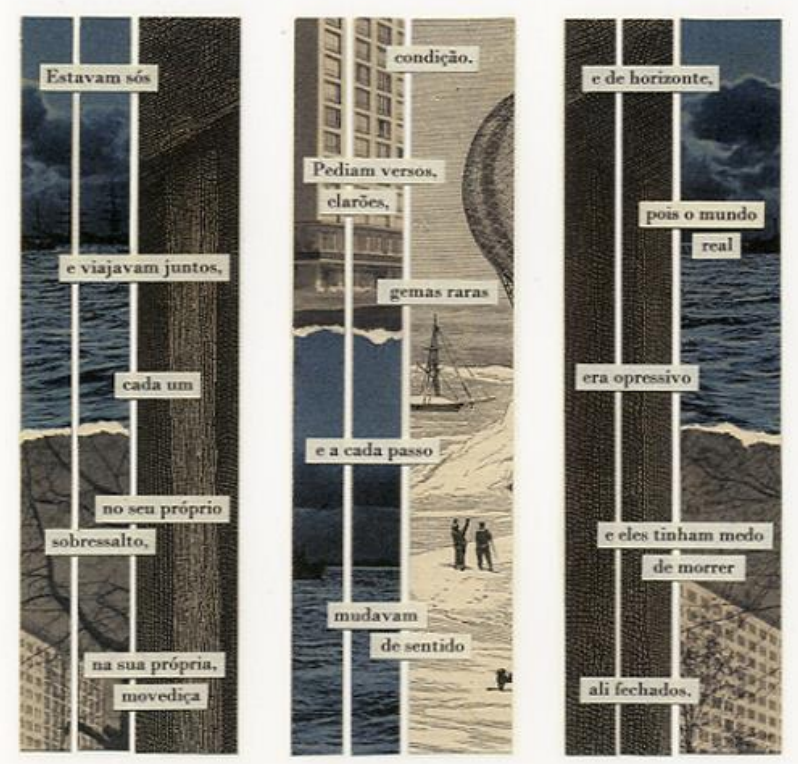

(Cabral 2012: 17)

Vemos quatro imagens cortadas e alternadas: a do mar, a de um prédio com árvores sem folhas, a do que parece ser uma madeira escura e a de uma provável aventura em altomar, com um monstro marítimo. O diálogo entre essas figuras e o que as palavras coladas sobre elas evocam vai desde o tom sombrio dos versos e a escuridão das cores das ilustrações a sutis detalhes como a concisão de "e eles tinham medo/ de morrer// ali fechados" com o prédio que, como toda a realidade no poema evocada, é um símbolo opressivo. O edifício, porém, tem janelas, oferecendo a possibilidade de fuga, mas para onde? Os sujeitos viajam tentando procurar um escape, mas não possuem um mapa que os guie nessa empreitada: "e a cada passo// mudavam/ de sentido// e de horizonte".

Essa fusão de materiais heterogêneos na página lembra a collage, técnica desenvolvida principalmente por artistas cubistas, futuristas e surrealistas que insere diferentes texturas e objetos em telas. Comentando sobre "Português", obra do francês Georges Braque que utiliza letras e numerais na tela, Clement Greenberg (2013: 97) diz que:

Quando se olha, as letras e numerais simulando a impressão com estêncil trocam de lugar, em termos de profundidade, com o ornamento, e por um instante a própria superfície física torna-se parte da ilusão: ela parece recuada em profundidade juntamente com a simulação de impressão com estêncil, de modo que o plano da pintura parece ser destruído mais uma vez - mas somente pela fração de um 
outro instante. O efeito duradouro é um movimento constante de vaivém entre a superfície e a profundidade, em que a superfície pintada é "infectada" pelo que não é pintado. Em vez de ser enganado, o olho fica intrigado; em vez de ver objetos no espaço, ele não vê nada além de uma pintura.

Acredito que o movimento de vaivém aludido pelo supracitado Greenberg também pode ser percebido nos poemas de Biblioteca dos rapazes, na medida em que os olhos de seus leitores também podem ficar intrigados pela sobreposição de imagens e versos. De fato, é possível relacionar a collage com o mecanismo da citação, já que ambos têm na apropriação seu fundamento. Se naquela juntam-se à tela elementos materiais, como pedaços de tecido ou de madeira, nesta juntam-se às palavras de quem escreve outras palavras anteriormente publicadas. Utilizando-se de dois mecanismos que, portanto, se assemelham, RPC passou a compor livros que adotam a collage juntamente com a citação, criando o que podemos chamar de poesia-colagem. ${ }^{5}$

Para alguns estudiosos, tais como Anne-Marie Christin (2001 apud Arbex 2006: 11), a imagem exerceu um papel fundamental na invenção e evolução da escrita e, dessa maneira, esta não possui somente a linguagem oral como referência. Com essa perspectiva, credita-se à invenção da superfície o nascimento da imagem e da escrita, uma vez que o pensamento em tela possibilitado pela superfície permitiu ao homem desenhar tanto figuras quanto letras sobre um suporte, estando imagem e escrita unidas desde suas origens (Arbex 2006). É preciso, então, pensar esse suporte: "É de certa forma o próprio suporte que detém uma energia de escrita, é ele que escreve e essa escrita me contempla" (Barthes apud Arbex 2006: 26).

Se os espaços em branco ganham importância desde Un coup de dés de Mallarmé, reintegrando a iconicidade e a espacialidade da escrita, a partir do século XX "a literatura reinveste e integra a parte visual e espacial da escrita" (Arbex 2006: 29), o que também pode ser visto na obra aqui analisada. Rui Pires Cabral trabalha os espaços em branco desde o início de sua obra, porém nos poemas-colagens a questão torna-se mais complexa: o próprio fundo - a página em branco - é preenchido por fragmentos colados, restando apenas algumas colunas em branco que dividem as três colunas de imagens e versos (as mais largas) ou que invadem o objeto artístico, se intrometendo por entre as colagens (as mais finas), e 
as margens superiores, inferiores e laterais que envolvem o poema-colagem. 0 próprio fundo torna-se, assim, uma forma artística por meio da inserção e combinação de diferentes elementos nele, o que amplia ainda mais sua importância.

Essa mistura de materiais na superfície traz, no âmbito temático, a recorrência de motivos envolvendo a desorientação, que se relaciona tanto com a errância pelas formas trazida pelo livro quanto com a inconstância e imprevisibilidade da vida: nossa "movediça// condição" (17). Dentro desse contexto, a única certeza que se pode ter é a morte, outro tópico amplamente explorado nesses poemas, também aludido pela dedicatória in memoriam a Mário Rui Oliveira Pires Cabral, primo-irmão do poeta. ${ }^{6}$

Conforme apontámos em resenha sobre este livro (Pimenta 2013: 279-280), acreditamos ser possível também encontrar a morte da juventude nesses versos, sobretudo se pensarmos na inspiração bibliográfica para essa obra:

Assim, o espectro insistente em Biblioteca dos rapazes aponta simultaneamente para a fugacidade do tempo e para a morte de um ente querido que estava presente nesse tempo. E, sob essa dupla faceta, para o inescapável fim das coisas: no tempo e na matéria.

Mais do que uma constatação desse término, o livro, a partir da recolha de objetos antigos pessoais e da reunião de lembranças, constrói uma espécie de memorando que tenta recuperar esse tempo perdido. Longe de um projeto utópico, a poesia de Rui Pires Cabral problematiza sua própria condição, pois, ao mesmo tempo em que sabe ser vã a tentativa de fixar a juventude, encontra na poesia o único escape para eternizar suas recordações: “o Domínio// é o poema// que souberes encontrar". (11)

Esse diálogo com obras que são recortadas e recriadas, assim como a forma repartida das colagens, também está presente em Broken, livro seguinte do autor, publicado em 2013. Neste, porém, os poemas-colagem são inspirados em um único título. Em nota ao livro, nos diz o poeta:

O presente ciclo de poemas foi desenvolvido a partir de algumas palavras extraídas de Unbroken - $O$ Submarino Fantasma da Guerra de 1939-45, um relato autobiográfico de Alastair Mars publicado em 1957 pela Imprensa Nacional de Publicidade. Assim se quebrou, digamos, a história do HMS Unbroken. (Cabral 2013: s/p.) 
Ao quebrar, recortar, a história do submarino “Unbroken" (inquebrável), o poeta transforma-o em "Broken" (quebrado). As tesouras de Pires Cabral destroem o que, no domínio da ficção, se diz "inquebrável”, transformando esses recortes quebrados em um novo livro. Diferentemente do ocorrido na obra anterior, nesta o autor não explica a origem das fotos e ilustrações em preto e branco que são dispostas nas páginas, mas, em seu conjunto, elas carregam à primeira vista um tom mais sombrio e indeterminado do que o que encontramos em Biblioteca dos rapazes. Nos dez poemas-colagens que compõem o livro, observa-se uma única coluna dividida em quatro partes por linhas brancas. Dessas quatro partes, duas são preenchidas por um fundo preto enquanto as restantes possuem uma imagem uniforme com cortes horizontais (também em tons escuros) e uma ilustração ou fotografia em preto e branco. Enquanto os fundos negros e a imagem com cortes se repetem quase em todos os poemas, as ilustrações ou fotografias variam de página em página até ausentarem-se no penúltimo e último poema-colagem (este todo formado por fundos pretos), conforme podemos notar na sequência das últimas três páginas do livr
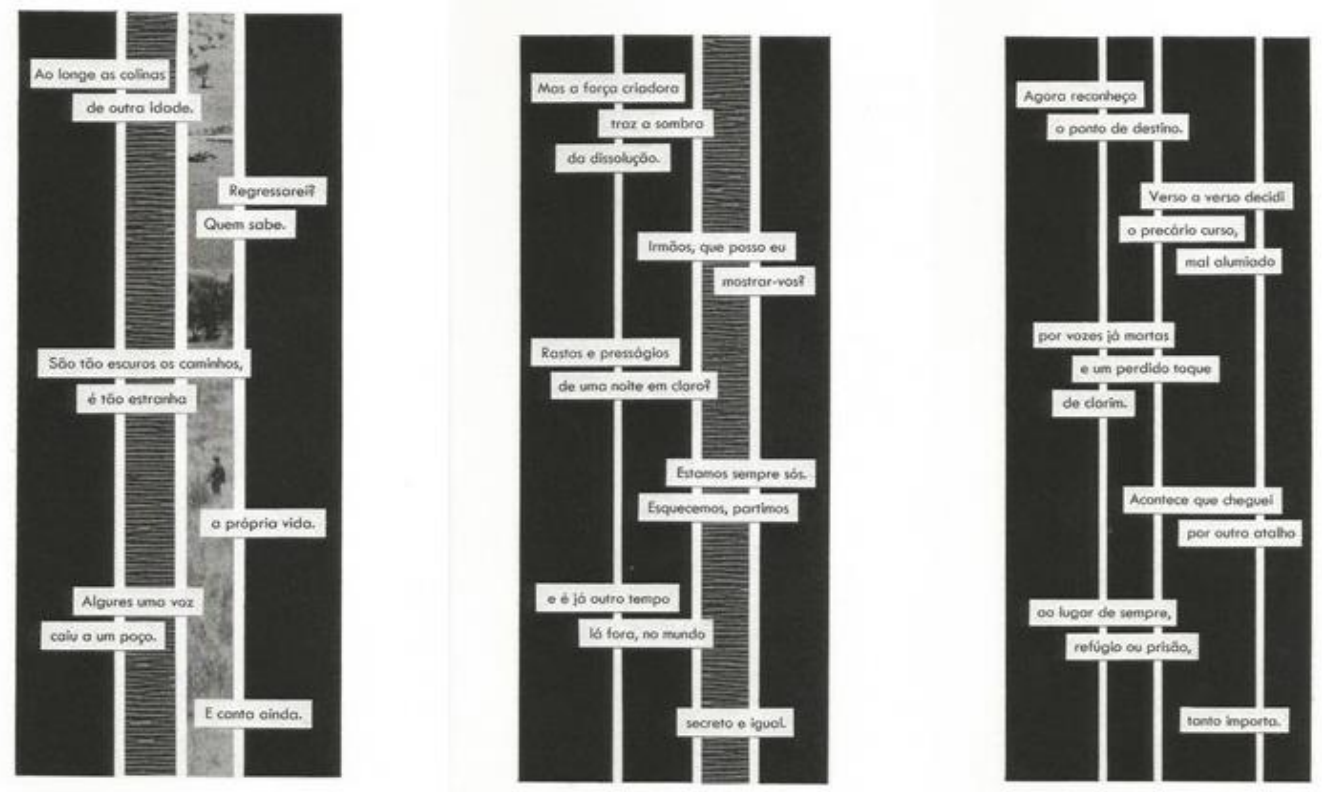

(Cabral 2013: s/p)

Desse modo, é como se os rostos desfocados e despersonalizados trazidos nos poemas-colagens fossem deixando o livro paulatinamente, assim como muitos dos passa- 
geiros do HMS Unbroken deixaram não só a embarcação, mas a própria vida nos combates empreendidos a bordo. Podemos observar, então, pontos de contato entre os poemas e o livro que foi "quebrado" para sua escritura: Unbroken, ao narrar a história de um submarino utilizado na Segunda Guerra Mundial, traz temas que são ressignificados em Broken. Talvez o mais presente deles seja o da morte que, com um enfoque diferente do que encontramos em Biblioteca, é entrelaçado à imagem do mar (evocada por vocábulos como "espuma", "corrente", "mar", "água", "submersos", "navegando"), onde simultaneamente pode-se ver e ser visto pela morte:

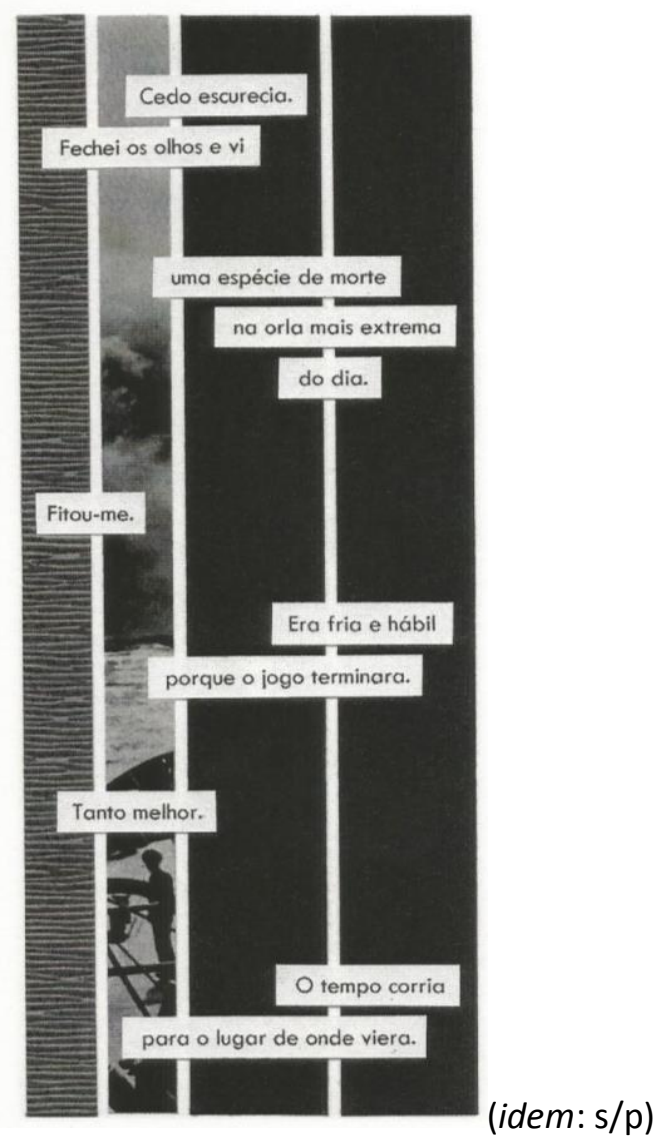

Nota-se neste poema a figura de um homem em um barco diante de um céu nebuloso e indicativo de tempestade, esse homem fita o cenário a sua volta da mesma forma que "uma espécie de morte" também o fita. Nesse contexto, ele sabe que "o jogo terminara" e que "O tempo corria/ para o lugar de onde viera": não há escape. Entretanto, se o regresso não é certo, o canto de uma voz ainda ecoa: 


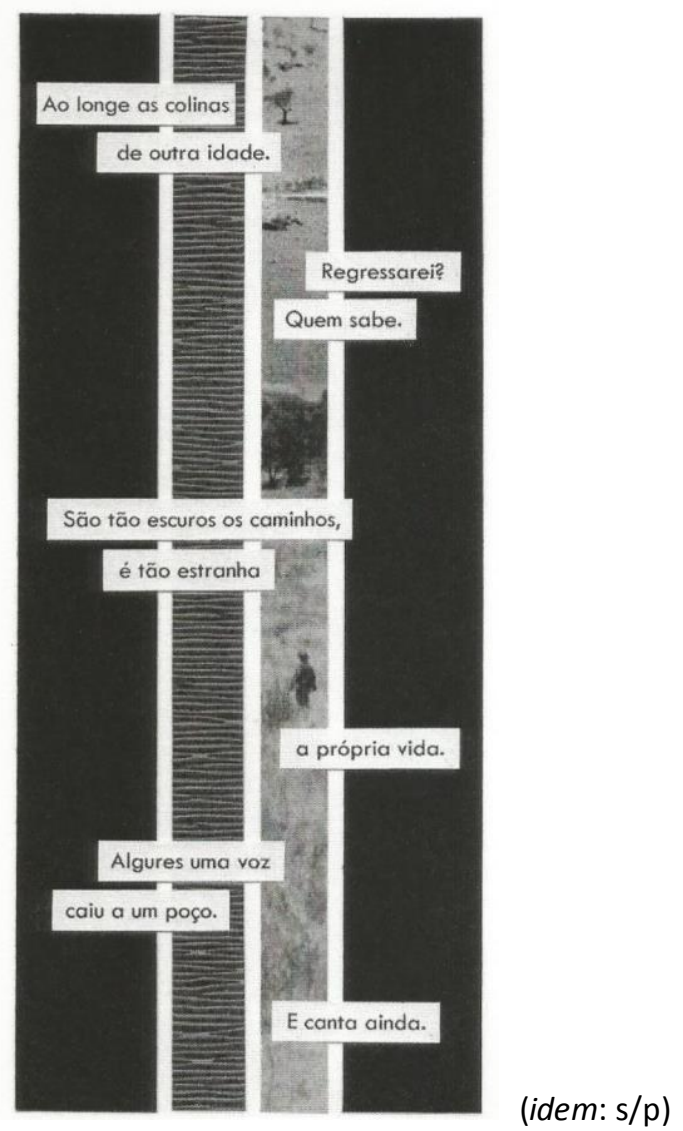

Se na autobiografia do capitão Mars são relatadas vivências e angústias submarinas, sobretudo acerca da luta pela sobrevivência, nos poemas-colagens de Rui Pires Cabral ecoa a permanente resistência em continuar tentando, ainda que, por vezes, o sentimento de descrença esteja a bordo fazendo doer "o peito/ de tanto esperar,// descrente/ e perdido// no meio do mar" (idem: $s / p$ ): e essa persistência está ligada à escrita, insistente companheiro de bordo. Assim, essas páginas trazem, juntamente com a viagem marítima que inspirou os dois livros, a viagem da escrita, igualmente penosa. Intricadas, elas se unem em expressões como "livro/ de espuma" e "mar rasgado// de papel velhíssimo", e no poema-colagem que fecha Broken reforçando que ambas excursões - pelo mar e pelo papel - trazem-nos "ao lugar de sempre": 


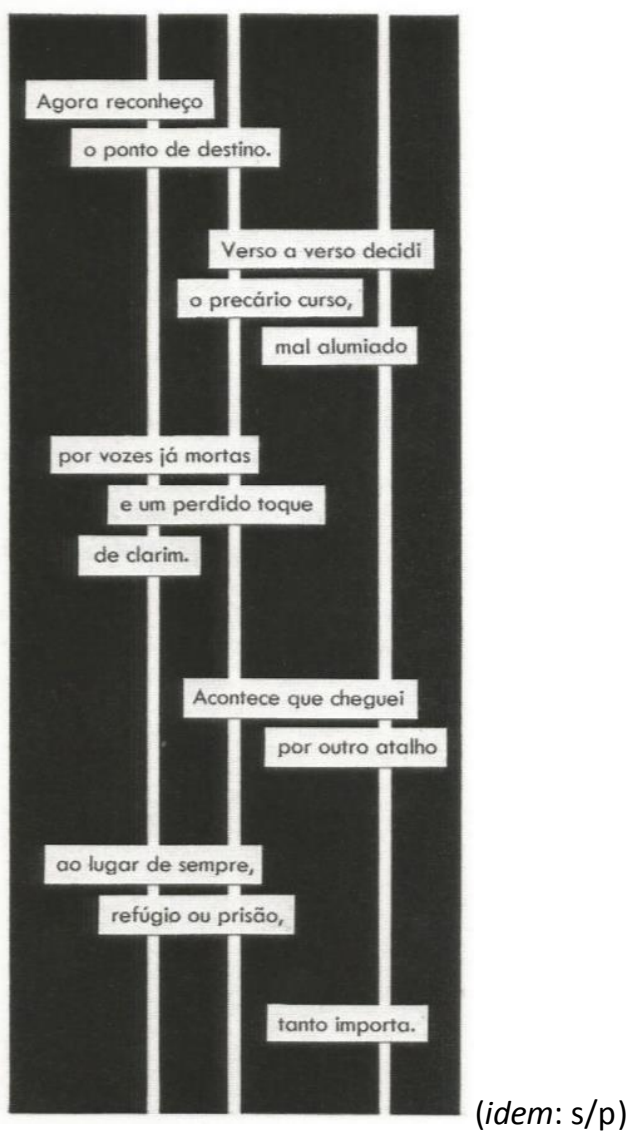

Seguindo a temática marítima, em 2014 RPC publicou Oh! Lusitania, anunciando na nota que abre o livro a elaboração "de uma trilogia em curso, de inspiração náutica" (Cabral 2014: s/p), da qual Broken seria o primeiro título, seguido por Oh! Lusitania e por outro livro ainda não publicado. Neste, encontramos vinte quatro poemas-colagens divididos em três seções: "the common difficulties"; "circling shadows"; e "the sunken room", cada uma composta por oito poemas. Assim como os títulos das partes, os versos são inteiramente em língua inglesa e, segundo o poeta, há uma boa razão para isto, já que "todos os poemas foram por assim dizer escritos com palavras recortadas do livro The Last Voyage of the Lusitania (A.A. Hoehling e Mary Hoehling, Pan Books, 1959), no qual se relata a tragédia do transatlântico afundado por um torpedo alemão na primavera de 1915. " (idem: s/p). 0 título, porém, foi retirado de The Malay Archipelago, livro com as observações do naturalista Alfred Russel Wallace durante suas viagens pela parte sul do arquipélago malaio entre 1854 e 1862. No capítulo vinte e seis desse livro, $^{7}$ ao avistar belos fortes originalmente 
construídos pelos portugueses séculos antes, Wallace comenta: "Oh! Lusitania, how art thou fallen!" (“Oh! Lusitânia! Como caíste!").

Sobrepõem-se, portanto, duas referências distintas, baseadas em cenários igualmente distantes: Lusitania, o navio americano que afundou na costa irlandesa após ser atingido por um torpedo alemão durante a 1ạ Guerra Mundial; e Lusitânia, relativo à nação portuguesa nos finais do século XIX, marcada pela queda de seu domínio ultramarino e colonial estabelecido três séculos antes. Duas imagens de queda e ruína, que representam a destruição do que outrora parecia inabalável (o império português e o navio, altamente tecnológico para a época). Essas são as nuances trabalhadas em Oh! Lusitania, que contrasta o preto e tons de vermelho alaranjado com fotografias em preto e branco que parecem ter sido arrancadas de sua origem violentamente, a julgar por suas formas e acabamento:

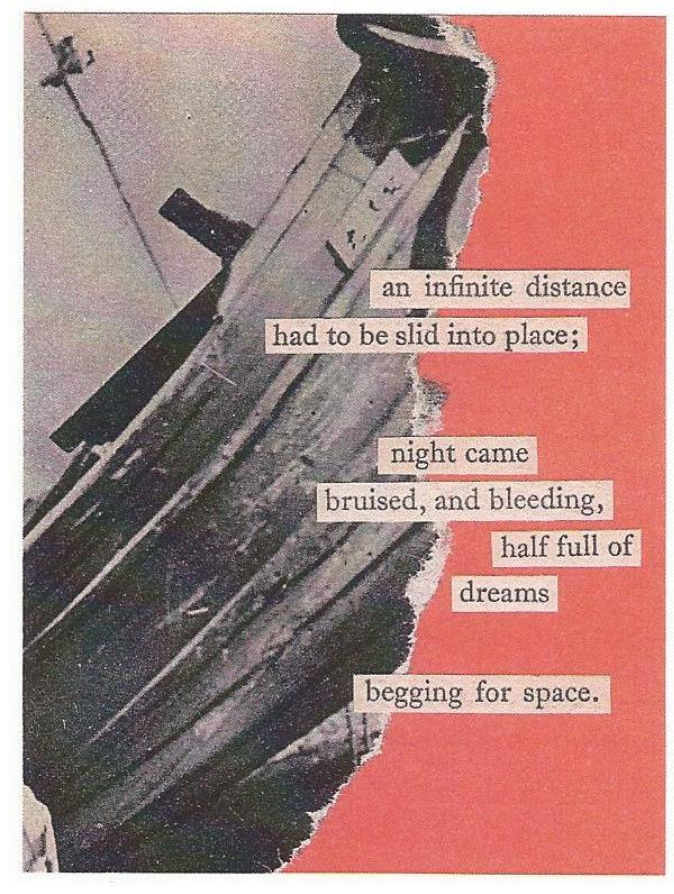

(idem: s/p)

Novamente encontramos imagens marítimas através do navio e do mar, mas também rostos desfocados que parecem gritar em desespero. Assim, os poemas-colagens deste livro parecem conduzir-nos a uma atmosfera de descrença ("a white/ city/ changed to grey"; "clouds grew darker" ), perturbação ("to set/ all souls// adrift"; "If only/ they could// stop// the doubts,/ the fears") e terror ("he could/ hear/ the language/ of fear"; "bodies/ are meant for/ night traffic/ and pain"; "too late to try"; "the idea of/ screaming// under 
water"). Dentro desse contexto, os passageiros dessa embarcação arruinada engatinham e agem como refugos:

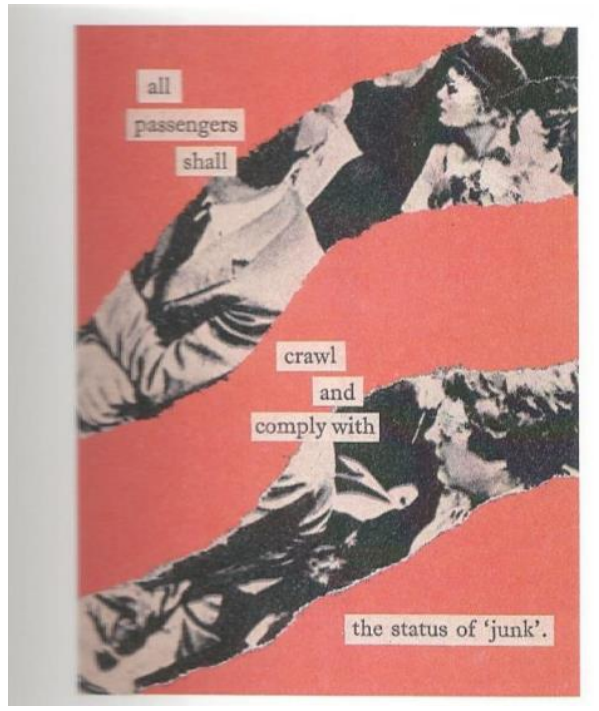

(idem: $\mathrm{s} / \mathrm{p}$ )

Entretanto, ainda que seja tarde para o canto - "sir,/ it's too late/ for singing" - e que seja fácil perder as palavras nessas circunstâncias - "words/ are// easy to lose" -, a música parece ainda encontrar caminhos entre os mortos para eclodir:
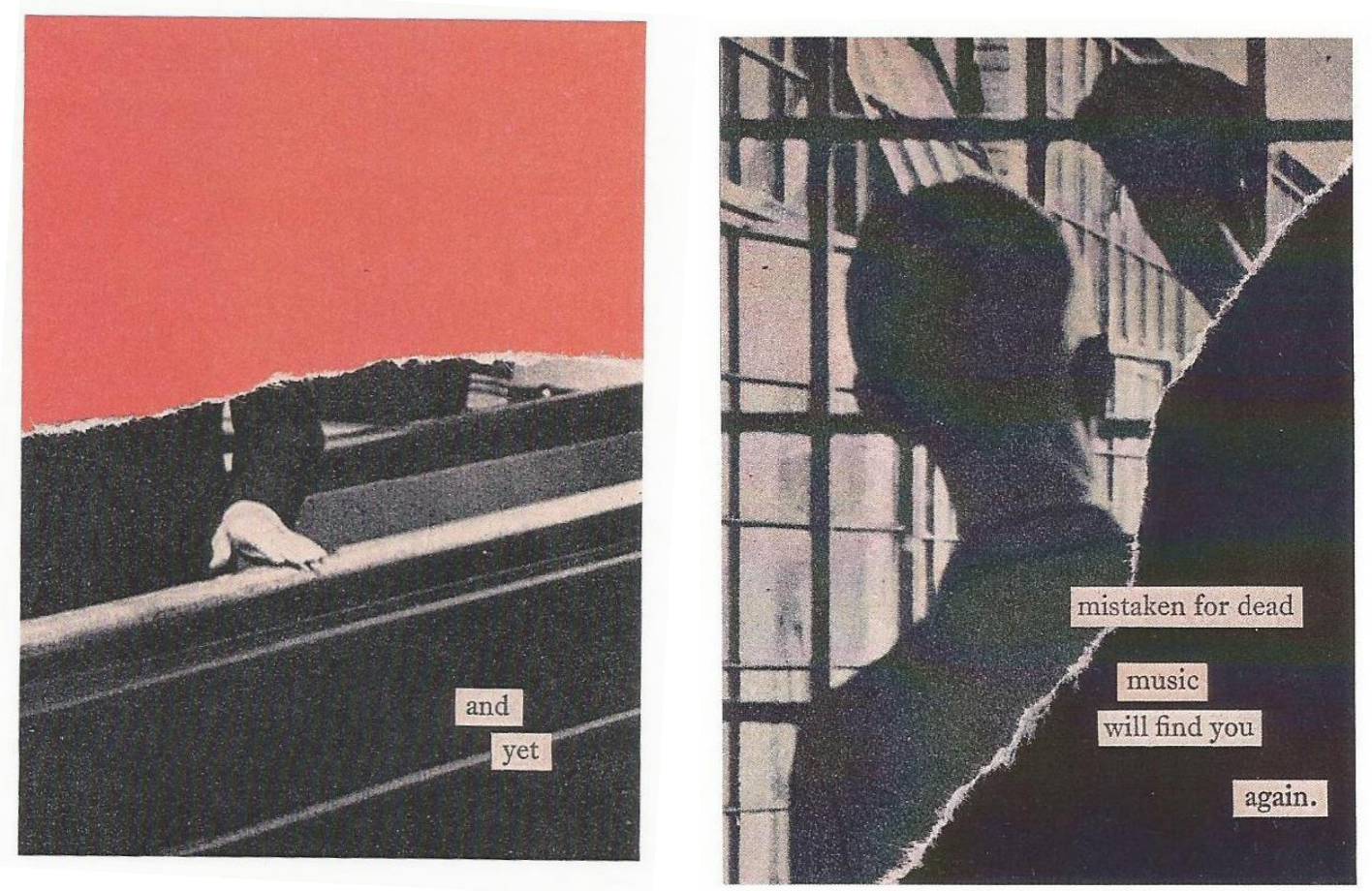

(idem: $\mathrm{s} / \mathrm{p}$ ) 
A mão pousada no que aparenta ser um deque de barco e o rosto que olha pela janela que observamos nesses poemas, que encerram Oh! Lusitania, são imagens de figuras que, embora desassossegadas, ainda esperam por algo que as liberte do quarto afundado em que estão presas. E os versos colados sobre elas, como já notado, parecem indicar o único elemento que as encontrará novamente: a música.

Desse modo, os dois livros que até o momento compõem a trilogia iniciada por Rui Pires Cabral - Broken e Oh! Lusitania - têm como plano de fundo momentos trágicos da história ocidental (1a e 2a Guerra Mundial) e portuguesa (queda do domínio marítimocolonial e subordinação ao poder inglês, que culminará no Ultimato de 1890), mas apontam para um certo refúgio dessas circunstâncias proporcionado pela escrita, pelo canto que insistirá a vir.

Por meio da problematização das relações entre poesia e imagem e, consequentemente, dos limites do gênero poético, os poemas-colagens de RPC constantemente deslocam conceitos e amarras, mantendo-se em um contínuo movimento intermidiático ao qual chamamos nomadismo poético. Além dos três títulos aqui estudados, esses diálogos também são explorados em outros livros de RPC, ${ }^{8}$ tais como Álbum (2013), Stardust (2013) e Elsewhere/alhures (2015) e, provavelmente, ainda o serão em publicações futuras deste poeta que, por uma constante errância por mídias, está a construir o espaço entre que é, afinal, o de sua poesia. 


\section{Bibliografia}

Arbex, Márcia (Org.) (2006), Poéticas do visível: ensaios sobre a escrita e a imagem, Belo Horizonte, UFMG.

Barros, Manoel de (2009), "Palavra de poeta: conversando com o fazedor de amanhecer", in Soares, Rosidelma Pereira Fraga, Convergências e tessituras de pedras, rios, ilhas e ventos: Manoel de Barros, João Cabral de Melo Neto e Corsino Fortes, 164 f, Dissertação (Mestrado em Estudos Literários) - Programa de Pós-Graduação em Letras e Linguística, Universidade Federal de Goiás, Goiânia.

-- (2006) "Manoel de Barros se considera um songo, parte II", Overmundo, Entrevista a Cláudia Trimarco, < $\quad$ http://http://www.overmundo.com.br/overblog/manoel-de-barrosseconsidera-umsongo-parte-ii> (último acesso em dezembro de 2015).

Cabral, Rui Pires (2005), Longe da Aldeia, Lisboa, Averno.

-- (2012), Biblioteca dos rapazes, Lisboa, Pianola.

-- (2013), Broken, Lisboa, Paralelo W.

-- (2014), Oh! Lusitania, Lisboa, Paralelo W.

Clüver, Claus (2006), “Inter textus/ inter artes/ inter media”, Aletria, Belo Horizonte: 11-41.

Compagnon, Antoine (2007), O Trabalho da Citação, tradução de Cleonice P. B. Mourão, Belo Horizonte, Editora UFMG.

Dal Farra, Maria Lucia (2007), “Rui Pires Cabral ou a poética andeja”,in Maffei, Luis (Org.), Portugal, 0, Rio de Janeiro, Oficina Raquel.

Greenberg, Clement (2013), Arte e cultura, tradução de Otacílio Nunes, São Paulo, Cosac Naify.

Perloff, Marjorie (2013), O gênio não original: poesia por outros meios no novo século, tradução de Adriano Scandolara, Belo Horizonte, Editora UFMG.

Pimenta, Tamy de Macedo (2013), "Biblioteca dos Rapazes, de Rui Pires Cabral", Convergência Lusíada, n. 29. 
Rajewsky, Irina O (2012), "Intermidialidade, intertextualidade e 'remediação'”, in Diniz, Thaïs Flores Nogueira (Org.), Intermidialidade e estudos interartes, Belo Horizonte, Editora UFMG. Süssekind, Flora (2005), “Desterritorialização e forma literária. Literatura brasileira contemporânea e experiência urbana", in Literatura e sociedade. Revista do Departamento de Teoria Literária e Literatura Comparada - USP, São Paulo, USP, n.1: 60-81.

\section{NOTAS}

\footnotetext{
${ }^{1}$ Mourier-Sasile/ Moncond'huy. L'Image génératrice de textes de fiction, p.4. Publicação do grupo de pesquisa Lisible/Visible, da Faculté des Lettres et des Langues de L'Université de Poitiers, decorrente do colóquio realizado pelo grupo em 1994, tendo por tema "a imagem geradora de textos de ficção".

2 Tratamos mais extensivamente sobre esse aspecto da poesia de Rui Pires Cabral em nossa dissertação de Mestrado, "Percursos do nomadismo na poética de Rui Pires Cabral", e no texto para o VI SAPPIL, disponível em < http://www.anaisdosappil.uff.br/index.php/VISAPPIL-Lit>.

${ }^{3}$ Claus Clüver, por sua vez, baseado no livro de Jörg Helbig sobre o assunto, pensa em três formas de relações abarcadas pelo conceito de intermidialidade: relações entre mídias em geral (relações intermidiáticas); transposição de uma mídia para outra (transposições intermidiáticas ou intersemióticas); união (fusão) de mídias (Clüver 2006: 24).

${ }^{4}$ A partir deste momento utilizaremos essa abreviação para nos referirmos ao poeta.

${ }^{5}$ Em Álbum (2013), há uma nota de fim que menciona o termo pela primeira vez em publicações do poeta: “ÁLBUM, 10 poemas-colagens de Rui Pires Cabral sobre fotografias de autores desconhecidos, é uma edição artesanal de 52 exemplares numerados e assinados pelo autor em 16 de Outubro de 2013" (Cabral 2013: s/p).

${ }^{6}$ Informações fornecidas pelo poeta em conversa informal de 2012.

${ }^{7}$ Disponível em <https://ebooks.adelaide.edu.au/w/wallace/alfred russel/malay/chapter26.html>.

${ }^{8}$ Fora da obra publicada de RPC, alguns poemas-colagens foram exibidos em duas pequenas exposições: 12 Poemas (Para Ler/Ver no Paralelo W), entre meados de junho e finais de julho de 2013 na livraria Paralelo W; e Rente ao Verso, no extinto bar Bartleby entre abril e maio de 2012, em parceria com a ilustradora Daniela Gomes. (Informações cedidas pelo poeta em conversa informal em 2015).
} 